\title{
EVOLÚCIÓS PSZICHOLÓGIA - AZ ELMÚLT 30 ÉV
}

\author{
BERECZKEI TAMÁS ${ }^{1 *}$ - TOPÁL JÓZSEF ${ }^{2}$ \\ ${ }^{1}$ Pécsi Tudományegyetem, Pszichológiai Intézet, Budapest, Magyarország \\ ${ }^{2}$ TTK Kognitív Idegtudományi és Pszichológiai Intézet, Budapest, Magyarország \\ E-mail: bereczkei.tamas@pte.hu
}

Benyújtva: 2021. március 19. - Elfogadva: 2021. április 19.

\begin{abstract}
Tanulmányunkban arra teszünk kísérletet, hogy áttekintsük a hazai pszichológiai életben megjelenö és egyre markánsabb szerepet játszó evolúciós megközelítéseket. Bemutatjuk a 30 évvel ezelôtti állapotokat és azokat a neves kutatókat, akik az evolúciós pszichológia magyarországi létrejötte mellett bábáskodtak. Ezt követöen részletesen is beszámolunk azokról a kutatásokról, amelyek a két nagy hazai evolúciós kutatómúhelyben jöttek létre, nevezetesen a Pécsi Evolúciós Pszichológia Kutatócsoportban és az MTA-ELTE Összehasonlító Etológiai Kutatócsoportból kinốtt teamekben. Végül röviden bemutatjuk azokat az eredményeket, amelyek e két nagy mühelyen kíül születtek egy-egy pszichológiai jelenség evolúciós értelmezése kapcsán.
\end{abstract}

Kulcsszavak: Csányi Vilmos, Pléh Csaba, Pécsi Evolúciós Pszichológiai Kutatócsoport, MTA-ELTE Etológiai Kutatócsoport

" Levelezô szerzô

(C) 2021 A szerzố(k) 
Az evolúciós pszichológia az elmúlt 30 évben fokozatosan és növekvô sikerrel jelent meg és hódított teret a hazai pszichológiai gondolkodásban. A pszichológiai jelenségek evolúciós szemléletû megközelítése a korábban létezô paradigmák és tudományágak (humán etológia, kognitív etológia, humán szociobiológia, viselkedésökológia) integrációjából jött létre, ezt a széles magyarázókeretet nevezzük evolúciós pszichológiának. Ebben a tekintetben az evolúciós pszichológia tehát egyszerre egy önálló diszciplína, másrészt egy szemléleti forma: az emberi viselkedés és gondolkodás sajátos megközelítése.

I.

Az evolúciós gondolkodásnak a hazai pszichológiai életben történô meghonosításában mindenekelôtt két nevet érdemes kiemelni. Az egyik Csányi Vilmos, aki szakmai munkájának nagy részét a humán evolúció kérdéskörének szentelte, és ebben nem csupán tudományos nóvumot teremtett, hanem egyúttal az evolúciós magyarázatok tágabb értelemben vett elterjesztését, megerôsítését is szolgálta. Széles ívú pályája egyaránt felölelte az evolúció általános folyamatleírását, a kutyák kognitív képességeinek tanulmányozását és bizonyos viselkedési vonások etológiai vizsgálatát (Csányi, 1989, 1999). Olyan iskolát hozott létre (ld. VI. rész), amely jelenleg is meghatározó szerepet játszik a hazai és nemzetközi kutatásban.

A másik kulcsfontosságú személy ebben a tekintetben Pléh Csaba, aki széles körű ismereteivel és tekintélyével a kezdetben vonakodó hazai pszichológusokat is meggyôzte az evolúciós szemlélet fontosságáról a lelki jelenségek értelmezésében. Írásai rendkívül sokoldalúak, egyaránt magukba foglalják az evolúciós episztemológia elméleti kérdésköreit, továbbá bizonyos konkrét jelenségek (pl. pszichopatológiai megnyilvánulások) evolúciós modelljeit (Pléh, 2001, 2009; Pléh és Boross, 2015). Az utóbbi idôben nagyon fontosak azok a munkái, amelyekben a pszichológia tudományát meghatározott szervezô elvekre építi, és a tanulmányozott jelenségeket az evolúcióagy-kultúra hármasságában értelmezi (Pléh, 2021). Pléh Csaba nem csupán a kortárs pszichológusokra gyakorolt jelentôs hatást, hanem számos pszichológushallgatót és doktoranduszt indított el azon a pályán, amelyen az evolúciós megközelítés és gondolkodás meghatározó szerepet játszik.

II.

Ami az elmúlt 30 év szakmai-társadalmi hátterét illeti, érdemes megjegyezni, hogy az evolúciós szemlélet meghonosítása a magyar pszichológiai életben már nem járt olyan nehézségekkel - esetleg politikai buktatókkal -, amelyek a korábbi idôszakot jellemezték. Ugyanakkor szembe kellett nézni bizonyos ellenérzésekkel és félreértésekkel, amelyek elsôsorban olyanok részérôl fogalmazódtak meg, akik egy teljesen más pszichológiai örökséget vallottak magukénak. Ezért idôbe tellett, amíg az evolúciós szemlélet mint új paradigma, elfogadottá vált a magyar pszichológiai közgondolkodásban, és elfoglalta helyét a konferenciákon, folyóiratokban, tankönyvekben, monográfiákban. 
Ebben a folyamatban, fôleg a 2000-es évektôl kezdôdôen, mindkét oldal toleranciát mutatott. A pszichológusok elfogadták, hogy az evolúciós megközelítés a jelenségek eltérố szintjére vonatkozik, és tökéletesen összeilleszthetô más pszichológiai magyarázatokkal. Az evolúciós szakemberek pedig arra törekedtek, hogy elsôsorban kísérleteik, empirikus munkáik - és kevésbé elméleti értekezéseik - révén alapozzák meg ezt az integrációt.

III.

Az elmúlt negyedszázadban Magyarországon két olyan tudományos múhely múködik, amely kifejezetten az emberi gondolkodás és viselkedés evolúciós megközelítésével foglalkozik. Az egyik a Pécsi Evolúciós Pszichológiai Kutatócsoport, Bereczkei Tamás vezetésével. A másik az alapvetôen állatmodelles megközelítéseket alkalmazó, a Csányi Vilmos által alapított MTA-ELTE Összehasonlító Etológiai Kutatócsoportból kinốtt teameket foglalja magába. Ez utóbbiak az ELTE Etológia Tanszékén, illetve a Kognitív Idegtudományi és Pszichológiai Intézetben tevékenykednek Miklósi Ádám, illetve Topál József vezetésével. Ugyanakkor hozzá kell tenni, hogy evolúciós pszichológiai kutatások elszórtan máshol is megtalálhatók, elsôsorban budapesti, szegedi, debreceni tanszékeken és kutatóintézetekben, többnyire olyan szakemberek kezdeményezésére, akik a fenti kutatócsoportok valamelyikében végezték korábban a munkájukat.

Azt is érdemes megemlíteni, hogy az evolúciós pszichológia oktatása valamilyen formában és valamilyen elnevezéssel minden magyarországi képzóhelyen folyik. Legjelentôsebb fórumnak a pécsi képzés mutatkozik, ahol az alapszakos hallgatók két féléven keresztül tanulnak evolúciós pszichológiát, a mesterszakon és a doktori képzésekben pedig külön szakirányok, programok és specializációk születtek e tárgy elsajátítására.

IV.

A két kiemelt tudományos múhely bemutatását kezdjük a pécsi kutatócsoporttal (www.evoluciospszichologia.hu). Egyik legfontosabb vonása a sokszínúség; az elmúlt 25 év során számos területen, számos témakörben végeztek kutatómunkát. A 80-as évek végi és a 90-es évek eleji útkereséseket inkább elméleti jellegú könyvek, tanulmányok, összefoglalók jellemezték (Bereczkei 1991). A 90-es évek közepétôl elinduló empirikus vizsgálatok az emberi viselkedés szinte minden területét érintették, annak az elgondolásnak az alapján, hogy a pszichológiai jelenségek minden típusa igényli az evolúciós gyökerek feltárását és ultimatív elemzését. Ennek szellemében foglalkoztak az Ormánságban élố beás cigányok rokonsági szervezôdésével, reproduktív stratégiáival, szülő-gyerek kapcsolatával, megállapítva, hogy ezek az interperszonális kapcsolatok jól értelmezhetôk olyan evolúciós modellek alapján, mint a Hamilton-elv, Trivers-Willard-hipotézis, helping-at-the-nest modell stb. (Bereczkei, 1998; Bereczkei és Dunbar, 2002). Az élettörténeti stratégiákra támaszkodó evolúciós szocializáció elméleti keretében sikerült értelmezni azokat az „átkapcsolásokat”, amelyek keretében 
a kedvezô és kedvezôtlen családi körülmények között felnevelt gyerekek más-más életpályára lépnek, eltérô adaptív fülkéket foglalnak el a szabályszegố viselkedés, iskolázottság, szexuális érés és termékenység tekintetében (Bereczkei és Csanaki, 1996, 2001). Ugyancsak új és átfogóbb értelmezést sikerült adni az alacsony testsúllyal született (és beteg) gyerekekkel kapcsolatos szülôi magatartásra; roma és nem roma populációkban végzett vizsgálatok arra mutattak rá, hogy itt egy olyan reproduktív stratégiáról van szó, amely növeli a fertilitást a gyermek csökkent túlélési esélyeire adott válaszként (Bereczkei, 2001). A kutatócsoport tagjai sokat foglalkoztak a párválasztással és az ezt befolyásoló tényezókkel, rámutatva, hogy a párválasztás preferenciái és kritériumai korunkban is evolúciós-adaptácionista struktúrákra épülnek (Bereczkei, Vörös, Gál és Bernáth, 1997; Conroy-Beam, Buss és Meskó, 2019).

A Pécsi Evolúciós Kutatócsoport két meghatározó témaköre az elmúlt mintegy másfél évtizedben egyfelôl az arc szexuális és szociális jelzéseire adott válaszok értelmezése, másrészt proszociális/proszelf viselkedést meghatározó hatások elemzése (utóbbi esetben különös tekintettel a machiavellizmusra). A költséges jelzés elmélete, a jó gén modell, illetve a hátrányelv alapján azt állították, hogy az arc egyes vonásai (beleértve a periférikus vonásokat, amilyen a haj) azért vonzóak esztétikai szempontból, mert jelzik tulajdonosaik átlag feletti egészségi állapotát, végsố soron genetikai sokféleségét (Meskó és Bereczkei, 2004; Meskó és Láng, 2019). A kutatócsoport kiemelt projektje volt egy évtizeden keresztül a hasonlóság alapján történô párválasztás (homogámia), amelyet egyrészt a fenotípusos illesztés, másrészt a szexuális imprinting etológiai modelljei alapján magyaráztak (Bereczkei, Gyuris és Weisfeld, 2004; Gyuris, Járai és Bereczkei, 2010; Kocsor, Saxton, Láng és Bereczkei, 2016). Végül az arcvizsgálatok az utóbbi években kibóvültek az arcon fellehetô szociális jelzések elemzésével, így például azzal, hogy a megbízhatóság kulcsai hogyan befolyásolják a szociális értékítéleteket, és milyen kölcsönhatásban vannak a vonzerô tulajdonságaival (Kocsor, Kozma, Neria, Jones és Bereczkei, 2019; Putz, Palotai, Csertő és Bereczkei, 2016). Ezekben a vizsgálatokban a „hagyományos” pszichológiai módszereken túl olyan kísérleti paradigmákat használtak és használnak, amelyek lehetôvé teszik az arcvonások és arányok számítógépes mérését és transzformációját.

\section{V.}

A másik nagy kutatási projekt elóbb a proszociális, majd késôbb (az elmúlt 6-8 évben) a proszelf magatartásminták elemzését túzte ki célul. A jelenlegi nemzetközi pszichológiai kutatásban rendkívül ritka „real life” vizsgálatokat végeztek annak a kérdésnek a megválaszolására, hogy mi tarthatta fenn az idegenek iránti önzetlenség és nagylelkúség humán motivációit az evolúció során, annak ellenére, hogy az ilyen viselkedés jelentôs költségekkel jár a rátermettségre nézve (Bereczkei, Birkás és Kerekes, 2007, 2010). Kiderült, hogy a karitatív tevékenységek többek között a referenciacsoport tagjai részérôl megnyilvánuló reputáció növelése érdekében történnek, amit a kísérletvezetôk a költséges jelzés elmélet alapján értelmeztek.

Ezt követôen a proszociális viselkedés „antipólusa”, a machiavellizmus elemzésére került sor, amelynek keretében a Pécsi Evolúciós Pszichológia Kutatócsoport a nem- 
zetközi kutatás élvonalába került, elsôsorban a manipuláció és megtévesztés kognitív, illetve szociális jellemzóinek vizsgálatai terén elért eredmények következtében. Kimutatták, hogy a machiavellisták - ellentétben például a pszichopatákkal - rugalmas stratégák, akik a mindenkori körülményeknek megfelelően változtatják célratörô taktikáikat (Czibor és Bereczkei, 2012; Birkás, Pátkai és Csathó, 2018). Olyan képességekben mutatnak átlagon felüli teljesítményt, mint a csoporttársak monitorozása, feladatorientáció, jutalomanticipáció, generalizáció, utilitárius gátlás, miközben az is kiderült, hogy - az elôzetes várakozással ellentétben - nem teljesítenek jól az elmeteória és az érzelmi intelligencia feladatokban (Bereczkei, 2015). Agyi képalkotó (fMRI) vizsgálatokat végezve a kutatócsoport tagjai olyan agyi területeket találtak (interior frontális tekervény, dorzolaterális prefrontális kéreg, jobb oldali thalamusz stb.), amelyek a szociális dilemma feladatok megoldása során erôteljes aktivitásnövekedést mutattak a machiavellista személyeknél (Bereczkei, Papp, Kincses, Bodrogi, Perlaki, Orsi és Deák, 2015). Végül, az eredmények összegzése és értelmezése után sikerült a 80-as években körvonalazódó Machiavelli Intelligencia Hipotézis új, modern verzióját megfogalmazni, amely szerint a humán (illetve primáta) evolúció során mások megtévesztése és kizsákmányolása hozzájárult a rátermettség növeléséhez, és ez szelekciós nyomást gyakorolt bizonyos kognitív képességek kifejlôdésére (Bereczkei, 2018).

\section{VI.}

Az evolúciós megközelítésû viselkedéstudományok másik nagy hazai múhelye az ELTE Etológia Tanszékén, illetve az MTA (majd ELKH) Kognitív Idegtudományi és Pszichológiai Intézetének keretei között végzi munkáját. Az 1990-es években megindult és fokozatosan kibontakozó kutatásaikat eredendôen az emberi viselkedés evolúciójának rendszerszemléletû megközelítése inspirálta. A Csányi Vilmos által kidolgozott elméleti alapvetés lényege, hogy szakított a korábbi modellek azon központi gondolatával, miszerint az emberré válás egy vagy néhány kulcstényezôn múlott, mint pl. a „megosztott intencionalitás” (Tomasello, Carpenter, Call, Behne és Moll, 2005). Ehelyett egy olyan megközelítést javasolt, miszerint a Pan-Homo törzsfejlődési vonalak szétválása után az emberi viselkedés evolúcióját apró, mozaikszerú, elsốsorban a társas viselkedést érintố változások sorozata jellemezte (Csányi, 1999, 2000). Vagyis az emberré válás történetét tulajdonképpen egy összetett viselkedésszabályozó rendszer egyes elemeinek egyidejû megjelenése és párhuzamos, egymásra kölcsönösen ható változásai kísérték. Az ennek nyomán három fô „dimenzióba” szerveződött humán viselkedési komplex (társas viselkedésformák, szinkronizációs viselkedési mechanizmusok és konstrukciós képességek) nemcsak alapvetôen újfajta értelmezési keretet biztosított az emberi viselkedés evolúciós történetének megértéséhez, hanem utat nyitott az olyan állatmodelles összehasonlító kutatások felé, amelyek az evolúciós pszichológia számára is releváns eredményekkel szolgálhatnak.

Az összehasonlító módszer alapvetố sajátossága ugyanis, hogy a közös törzsfejlôdési múltnak köszönhetô homológ tulajdonságok elemzésén alapuló vizsgálatok mellett legalább olyan fontos az evolúciós analógiák keresése, azaz az olyan fajok vizsgálata, amelyek bár törzsfejlôdésileg távol állnak az embertől, de társas-kognitív képességeik 
kialakulását az emberéhez hasonló adaptációs kényszerek kísérhették. A különbözô fajok azonos környezeti feltételekhez való adaptálódása olyan konvergens evolúciós folyamatot eredményez, mely az eltérô törzsfejlôdési alapok ellenére is hasonló jellemvonások, funkcionális analógiák kialakulásához vezethet. Lényegében ez a felismerés jelentette az alapvetô inspirációt arra, hogy az összehasonlító elmekutatás fókuszába olyan, az embertôl törzsfejlôdésileg távol esô faj kerüljön, mint a kutya. E rendszerszemléletú megközelítés elméleti megalapozása (Topál, Miklósi és mtsai, 2009), valamint az a felismerés, hogy a kutya alkalmas modellállatként szolgál az emberi társas-kognitív képességek evolúciójának megértésében (Miklósi és Topál, 2013), az elmúlt másfél évtizedben jelentôs tudományos visszhangot váltott ki.

VII.

A kutya - mint modellfaj - bevezetése az emberi társas viselkedés és kognitív képességek vizsgálatába nemzetközileg is elismert kutatási irányzattá nôtte ki magát, s a magyar kutatóhelyek e vonatkozásban alapvetô szerepét egy nemrégiben megjelent áttekintô tanulmány és metaanalízis is egyértelmúen kiemeli (Alterisio, Scandurra, Pinelli és D’Aniello, 2020). A hazai kutatócsoportok által végzett kísérletes vizsgálatok eredményei összességében megerôsítik azt a hipotézist, hogy a humán viselkedési komplex egy minimális készlete - funkcionális analógiák formájában - a kutyában is jelen van. E párhuzamok jól tetten érhetôk például a kötôdés mint pszichoszociális mechanizmus vonatkozásában. Ezt igazolja az is, hogy az eredetileg anya-csecsemó kötődés vizsgálatára kidolgozott módszer (Ainsworth és Wittig, 1969) alkalmasnak bizonyult a kutya-gazda kapcsolat elemzésére. A felnôtt családi kutyák ugyanis a kisgyerekekre jellemzô kötődési viselkedési mintázat jellegzetes elemeit mutatják (Topál, Miklósi, Dóka és Csányi, 1998), és amint az a kutya és farkas közötti összehasonlító vizsgálatokból kiderült, ez az érdekes párhuzam valószínúleg a háziasítás specifikus viselkedésevolúciós terméke (Topál, Gácsi, Miklósi, Virányi, Kubinyi és Csányi, 2005).

Az elmúlt években jelentôs visszhangot kiváltó eredmények születtek a kommunikációs készségek kutya és ember közötti párhuzamait tekintve is. Egyebek mellett igazolást nyert, hogy a kutyák prediszponáltak az emberrel való szemkontaktusra, s ez azután jó lehetôséget teremt a kifinomult kommunikációs készségek elsajátítására és a társas interakciók kialakítására (Miklósi, Kubinyi, Topál, Gácsi, Virányi és Csányi, 2003). Kimutatták továbbá, hogy az emberrel való interakcióban a kutyák tekintetkövetô hajlandósága nagymértékben változik aszerint, hogy az iránymutató jelzéseket (pl. a tekintet elfordítása) megelôzôen megtörtént-e a közlési szándék kinyilvánítása (megszólítás és szemkontaktus felvétele). A közlési szándék kinyilvánítására való effajta érzékenység jellegzetesen demonstrálja a kutya humán-analóg kommunikációs készségeit (Téglás, Gergely, Kupán, Miklósi és Topál, 2012).

További, vezetố nemzetközi folyóiratokban (Science, Current Biology) megjelent közlemények erôsítették meg azt a vélekedést, miszerint a kutya figyelemre méltó és sok szempontból „gyerekszerü” viselkedési szinkronizációs készségekkel rendelkezik. A megfigyelt viselkedésre érzékenyen reagál, azzal kapcsolatban elvárásokat alakít ki, 
és ennek révén komplex információkat szerezhet (Topál, Gergely, Miklósi, Erdőhegyi és Csibra, 2008; Topál, Gergely, Erdôhegyi, Csibra és Miklósi, 2009). A kutya emberi kommunikációra való érzékenységét e kutatócsoportok újabban agyi képalkotó módszerekkel is vizsgálják. Kiderült például, hogy az emberi hangok érzelmi töltésére a kutyák is specifikus agyi válaszokkal reagálnak, s ez ugyanúgy a másodlagos hallókérgi területeken jelentkezik, mint az embernél (Andics, Gácsi, Faragó, Kis és Miklósi, 2014). Úgy tûnik továbbá, hogy a kutyák idegrendszere a szavak jelentését és intonációs jellegzetességeit elkülönülten dolgozza fel, annak ellenére, hogy valódi nyelvi megértô képességgel nem rendelkeznek (Andics, Gábor, Gácsi, Faragó, Szabó és Miklósi, 2016).

\section{VIII.}

E két nagyobb tudományos múhely eredményei mellett érdemes és szükséges említést tenni azokról a pszichológia különbözô területein tevékenykedô hazai kutatókról, akik nem feltétlenül tekinthetôk evolúciós pszichológusnak, de munkájukban vagy annak egy részében az evolúciós megközelítést teszik magukévá. Kiemelkedik közülük Gergely György és Csibra Gergely, akik több, komoly nemzetközi visszhangot kiváltó munkájukban kimutatták, hogy az ember születésétôl fogva rendelkezik egy társas tanulási rendszer, az ún. „természetes pedagógia” képességével, amely feltehetôleg óseink eszközhasználatában és társas kapcsolataiban gyökerezik (ld. pl. Gergely és Csibra, 2013). A magyar kutatók közül többen is foglalkoznak a csecsemôk és kisgyermekek különbözô kognitív képességeivel, és ehhez időnként az evolúciós pszichológia perspektíváját is felhasználják (Bátki, Baron-Cohen, Connellan, Wheelwright és Ahluwalia, 2000; Gervain és Mehler, 2010). Mások az evolúciós paradigma filozófiai vonatkozásaira helyezik a hangsúlyt, és egyfajta episztemológiai vagy metaelméleti keretként fogják fel (Nánay, 2000; Terestyéni, 2001). Születtek kiváló értelmezések a humor társas kapcsolatokban való használatának adaptív mintázatairól (Tisljár, 2016), az emberi agy és a kognitív funkciók kapcsolatának evolúciós történetérốl (Csathó, 2016), a gyermeki fejlốdés darwini megközelítésének fontosságáról (Péley, 2010) és a pszichopatológiák evolúciós gyökereirôl (Bátki és Pléh, 2008; Csányi és Miklósi, 2010; Gyuris, Meskó és Tisljár, 2014), hogy csak néhányat említsünk. Fontos megemlíteni az ELTE Szociálpszichológia Tanszékén folyó evolúciós pszichológiai orientációjú kutatásokat, amelyek elsôsorban a párválasztási preferenciákkal és a kapcsolati elégedettséggel foglalkoznak (Csajbók és Berkics, 2017).

Mindebbôl is látszik, hogy aligha van a pszichológiának olyan területe, amelyet az elmúlt 30 évben ne helyeztek volna evolúciós perspektívába. És ez egyáltalán nem meglepó, hiszen, az evolúciós pszichológia mint diszciplína egyik jellegzetes tulajdonsága éppen az integrálóképesség. Az a törekvés, amely a legkülönbözóbb lelki jelenségeket képes egy széles konceptuális keretben úgy elhelyezni, hogy az általa adott „végsô” alapelvekre biztonsággal lehessen építeni egy-egy jelenség konkrét magyarázatát. 


\section{IRODALOM}

Ainsworth, M. D. S., \& Wittig, B. A. (1969). Attachment and exploratory behavior of one-year olds in a strange situation. In Foss, B. M. (Ed.), Determinants of infant behavior, Vol. 4 (pp. 111-136). London: Meuthen.

Alterisio, A. M., Scandurra, A. Pinelli, C., \& D'Aniello, B. (2020). The scholar's best friend: research trends in dog cognitive and behavioral studies. Animal Cognition, 24, 541-553. DOI: https://doi.org/10.1007/s10071-020-01448-2

Andics, A., Gábor, A., Gácsi, M., Faragó, T., Szabó, D., \& Miklósi, Á. (2016). Neural mechanisms for lexical processing in dogs. Science, 353(6303), 1030-1032.

Andics, A., Gácsi, M., Faragó, T., Kis, A., \& Miklósi, Á. (2014). Voice-sensitive regions in the dog and human brain are revealed by comparative fMRI. Current Biology, 24(5), 574-578.

Bátki, A., Baron-Cohen, S., Connellan, J., Wheelwright, S., \& Ahluwalia, J. (2000). Is there an innate gaze module? Evidence from human neonates. Infant Behavior \& Development, 23(2), 223-229.

Bátki, A., \& Pléh, Cs. (2008). Evolúciós pszichopatológia: jelszavak és kérdôjelek. In Pléh, Cs., A lélek és a lélektan örömei (pp. 239-250). Budapest: Gondolat.

Bereczkei T.: A génektól a kultúráig. Szociobiológia és társadalomtudomány. Gondolat, Bp. 1991

Bereczkei, T. (1998). Kinship network, direct childcare, and fertility among Hungarian Gipsies. Evolution and Human Behavior, 19, 234-245.

Bereczkei, T. (2001). Maternal trade-off in treating high-risk children. Evolution and Human Behavior, 22(3), 197-212.

Bereczkei, T. (2015). The manipulative skill: Cognitive devices and their neural correlates underlying Machiavellian decision-making. Brain and Cognition, 99, 24-31.

Bereczkei, T. (2018). Machiavellian intelligence hypothesis revisited: What evolved cognitive and social skills may underlie human manipulation. Evolutionary Behavioral Sciences, 12(1), $32-51$.

Bereczkei, T., Birkás, B., \& Kerekes, Zs. (2007). Public charity offer as a proximate factor of evolved reputation-building strategy: An experimental analysis of a real life situation. Evolution and Human Behavior, 28(4), 277-284.

Bereczkei, T., Birkás, B., \& Kerekes, Zs. (2010). Altruism towards strangers in need: costly signaling in an industrial society. Evolution and Human Behavior, 31(2), 95-103.

Bereczkei, T., \& Csanaky, A. (1996). Evolutionary Pathway of Child Development; Lifestyles of Adolescents and Adults from Father-Absent Families. Human Nature, 7(3), 257-280.

Bereczkei, T., \& Csanaky, A. (2001). Stressful family environment, mortality, and child socialisation: Life-history strategies among adolescents and adults from unfavourable social circumstances. International Journal of Behavioral Development, 25(6), 501-508.

Bereczkei, T., \& Dunbar, R. (2002). Helping-at-the-nest and reproduction in a Hungarian Gypsy population. Current Anthropology, 43(5), 804-809.

Bereczkei, T., Vörös, A., Gál, A., \& Bernáth, L. (1997). Resources, attractiveness, family commitment; Reproductive decisions in mate choice. Ethology, 103(8), 681-699.

Bereczkei, T., Gyuris, P., \& Weisfeld, G. (2004). Sexual imprinting in human mate choice. Proceedings of Royal Society, 271, 1129-1134.

Bereczkei, T., Papp, P., Kincses, P., Bodrogi, B., Perlaki, G., Orsi, G., \& Deák, A. (2015). The neural basis of the Machiavellians' decision making in fair and unfair situations. Brain and Cognition, 98, 53-64.

Birkás, B., Pátkai, G., \& Csathó, Á. (2018). The Mediating Role of the Dark Triad Between Life History Strategy and Perceived Stress Factors. Psychological Reports, 191, 1-14. 
Conroy-Beam, D., Buss, D. M., Asao, K., Sorokowska, A., Sorokowski, P., Aavik, T. et al. (2019). Contrasting computational models of mate preference integration across 45 countries. Scientific Reports, 9(1), 16885.

Csajbók, Zs., \& Berkics, M. (2017). Factor, factor, on the whole, who's the best fitting of all? Factors of mate preferences in a large sample. Personality and Individual Differences, 114, 92102.

Csathó, Á. (2016). A kognitív funkciók és az emberi agy evolúciója. In Meskó, N., \& Gyuris, P. (Eds), Evolúciós pszichológia mesterfokon (pp. 93-112). Pro Pannónia Kiadó.

Csányi, V. (1989). Evolutionary Systems and Society. A General Theory of Life, Mind, and Culture. Durham-London: Duke University Press.

Csányi, V. (1999). Az emberi természet. Humánetológia. Budapest: Vince.

Csányi, V. (2000). The 'human behaviour complex' and the compulsion of communication: Key factors in human evolution. Semiotica, 128, 45-60.

Csányi, V., \& Miklósi, Á. (2010). Fékevesztett evolúció. Megszaladási jelenségek az emberi evolúcióban. Budapest: Typotex.

Czibor, A., \& Bereczkei, T. (2012). Machiavellian people's success results from monitoring their partners. Personality and Individual Differences, 53(3), 202-206.

Gergely, G., \& Csibra, G. (2013). Natural pedagogy. In Banaji, M. R., \& Gelman, S. A. (Eds), Navigating the Social World: What Infants, Chidren, and Other Species Can Teach Us (pp. 127-132). Oxford University Press.

Gervain, J., \& Mehler, J. (2010). Speech Perception and Language Acquisition in the First Year of Life. Annual Review of Psychology, 61, 191-218.

Gyuris, P., Járai, R., \& Bereczkei, T. (2010). The effect of childhood experiences on mate choice in personality tratis: Homogamy and sexual imprinting. Personality and Individual Differences, 49(5), 467-472.

Gyuris, P., Meskó, N., \& Tisljár, R. (Eds) (2014). Az evolúció árnyoldala: A lelki betegségek és az alternatív szexualitás darwini elemzése. Budapest: Akadémiai.

Kocsor, F., Saxton, T. K., Láng, A., \& Bereczkei, T. (2016). Preference for faces resembling opposite-sex parents is moderated by emotional closeness in childhood. Personality and Individual Differences, 96, 23-27.

Kocsor, F., Kozma, L., Neria, A. L., Jones, D. N., \& Bereczkei, T. (2019). Arbitrary signals of trustworthiness - social judgments may rely on facial expressions even with experimentally manipulated valence. Heliyon, 5(5), 1-12.

Meskó N., \& Bereczkei, T. (2004). Hairstyle as an adaptive means of displaying phenotypic quality. Human Nature, 15(3), 251-270.

Meskó, N., \& Láng, A. (2019). Acceptance of Cosmetic Surgery among Hungarian Women in a Global Context: the Hungarian Version of the Acceptance of Cosmetic Surgery Scale (ACSS). Current Psychology, 28, 234-256.

Miklósi, Á., Kubinyi, E., Topál, J., Gácsi, M., Virányi, Z., \& Csányi, V. (2003). A simple reason for a big difference: Wolves do not look back at humans but dogs do. Current Biology, 13, 763-766.

Miklósi, Á., \& Topál, J. (2013). What does it take to become 'best friends'? Evolutionary changes in canine social competence. Trends in Cognitive Sciences, 17(6), 287-294.

Nánay, B. (2000). Elme és evolúció. Budapest: Kávé Kiadó.

Péley, B. (2010). Fejlôdés és evolúció: Evolúciós szemlélet a fejlődésben, pszichopatológiában és a pszichoterápiában. Magyar Pszichológiai Szemle, 65, 65-83.

Pléh, Cs. (2001). Az evolúciós szemlélet felmerülése, eltûnése s újra felmerülése a pszichológiában. In Pléh, Cs., Csányi, V., \& Bereczkei, T. (Eds), Lélek és evolúció. Az evolúciós szemlélet és a pszichológia (pp. 13-59). Budapest: Osiris. 
Pléh, Cs. (2009). Darwin és a modern pszichológia funkcionalista megközelítése. Magyar Tudomány, 170, 386-393.

Pléh, Cs. (2021). A pszichológia kézikönyve. (Megjelenés alatt)

Pléh, Cs., \& Boross, O. (2015). Darwinism as a description key for the human mind. In Scott, R., \& Kosslyn, S. (Eds), Emerging Trends in the Social and Behavioral Sciences (pp. 1-16). New York: John Wiley \& Sons.

Putz, Á., Palotai, R., Csertô, I., \& Bereczkei, T. (2016). Beauty stereotypes in social norm enforcement: The effect of attractiveness on third-party punishment and reward. Personality and Individual Differences, 88, 230-235.

Terestyéni, T. (2001). A kommunikáció néhány evolúciós vonatkozása. In Pléh, Cs., Csányi, V., \& Bereczkei, T. (Eds), Lélek és evolúció. Az evolúciós szemlélet és a pszichológia (pp. 280-289). Budapest: Osiris.

Téglás, E., Gergely, A., Kupán, K., Miklósi, Á., \& Topál, J. (2012). Dog’s gaze following is tuned to human communicative signals. Current Biology, 22(3), 209-212.

Tisljár, R. (2016). A humor kialakulása és szerepe a kommunikációban. In Meskó, N., \& Gyuris, P. (Eds), Evolúciós pszichológia mesterfokon (pp. 306-322). Pro Pannónia Kiadó.

Tomasello, M., Carpenter, M., Call, J., Behne, T., and Moll, H. (2005). Understanding and sharing intentions: The origins of cultural cognition. Behavioral and Brain Sciences, 28, 675-690.

Topál, J., Miklósi, Á., Dóka, A., \& Csányi, V. (1998). Attachment behaviour in the dogs: a new application of the Ainsworth's Strange Situation Test. Journal of Comparative Psychology, 112(3), 219-229.

Topál, J., Gácsi, M., Miklósi, Á., Virányi, Zs., Kubinyi, E., \& Csányi, V. (2005). The effect of domestication and socialization on attachment to human: a comparative study on hand reared wolves and differently socialized dog puppies. Animal Behaviour, 70(6), 1367-1375.

Topál, J., Gergely, G., Miklósi, Á., Erdôhegyi, Á., \& Csibra, G. (2008). Infants perseverative search errors are induced by pragmatic misinterpretation. Science, 321(5897), 1831-1834.

Topál, J., Gergely, G., Erdôhegyi, Á., Csibra, G., \& Miklósi, Á. (2009). Differential sensitivity to human communication in dogs, wolves and human infants. Science, 325(5945), 1269-1272.

Topál, J., Miklósi, Á., Gácsi, M., Dóka, A., Pongrácz, P., Kubinyi, E., et al. (2009). Dog as a complementary model for understanding human social behavior. Advances in the Study of Behavior, 39, 71-116. 


\section{EVOLUTIONARY PSYCHOLOGY - THE LAST 30 YEARS}

\section{BERECZKEI, TAMÁS - TOPÁL, JÓZSEF}

In our paper, we make an attempt to overview those evolutionary approaches that have developed and become increasingly influencing in the Hungarian psychological life. We show the conditions 30 years ago, and those gifted scholars who contributed to the development of evolutionary psychology in Hungary. Then, we give a detailed review on the studies that have been fulfilled in the two basic research centers in Hungary: the Evolutionary Psychology Research Group of Pécs, and the MTA-ELTE Comparative Ethological Team. Finally, we describe the scientific results that have been achieved in the interpretation of specific psychological phenomena outside these main research centers.

Keywords: Vilmos Csányi, Csaba Pléh, Evolutionary Research Group of Pécs, MTA-ELTE Comparative Ethological Team

A cikk a Creative Commons Attribution 4.0 International License (https://creativecommons. org/licenses/by/4.0/) feltételei szerint publikált Open Access közlemény, melynek szellemében a cikk bármilyen médiumban szabadon felhasználható, megosztható és újraközölhetô, feltéve, hogy az eredeti szerzó és a közlés helye, illetve a CC License linkje és az esetlegesen végrehajtott módosítások feltüntetésre kerülnek. (SID_1) 